\title{
ROLE OF NON ENTREPRENEUR PARENTS AND ENTREPRENEURIAL EDUCATION IN IMPROVING INTEREST OF ENTREPRENEURSHIP IN HIGH SCHOOL XII STUDENTS
}

\author{
Imanuel Deny Krisna Aji \& Natalia Vike Theresia Sigar \\ School of Communication Science and Media Business, \\ Universitas Ciputra Surabaya, Surabaya, Indonesia
}

\begin{abstract}
The high unemployment rate in Indonesia is due to a lack of entrepreneurship. This situation occurs because people prefer to work as employees in the company rather than to run their own business. If the entrepreneurship interest in the community is low, efforts need to be made to increase that interest, especially for the younger generation. This study aims to determine the effect of entrepreneurship education and the role of parents as independent variables on the interest in entrepreneurship (dependent variable) high school students of class XII CB. The subjects of this study were all students of class XII CB. The type of research used in this study is quantitative descriptive. The data were collected using a questionnaire (questionnaire) with a Likert scale. Validation using Pearson showed correlation with a significance rate of 0.05 (5\%). The population of students of Class XII CB High School involved 28 students. This study found that entrepreneurship education and the role of parents had a linear relationship to the interest in entrepreneurship significantly. The correlation test showed a strong correlation (0.719) between entrepreneurship education and the role of parents with an interest in entrepreneurship. The coefficient of determination Adjusted R square was 0.479 (47.9\%), meaning that the independent variable has a strong percentage in explaining the dependent variable. The results of the $t$ test or partial test of entrepreneurship education had no significant influence on interest in entrepreneurship. The parents had a significant influence on students' interest in entrepreneurship, and the results of the $\mathrm{F}$ test showed that multiple linear regression models involving both independent variables were acceptable.
\end{abstract}

Keywords: entrepreneurship education, role of parents, interest in entrepreneurship

\section{Introduction}

One important indicator describing countries as prosperous is when they can have at least $2 \%$ of entrepreneurs or entrepreneurs. In 2016, according to data from the Central Statistics Agency (BPS), the ratio of entrepreneurs in Indonesia increased to $3.1 \%$, This means that the figure reflects more than the minimum standard of economic prosperity of a country.
However, the $3.1 \%$ ratio is not the same as other neighboring countries. Indonesia's per capita Gross Domestic Product (GDP) is relatively low. Indonesia's GDP per capita in 2016 reached 3974.9 USD. Singapore reached USD 52600.6 (Economics, 2018). Therefore, Indonesia still needs to increase the number of entrepreneurs to continue to encourage the progress of the country's economy.

\footnotetext{
*Corresponding Author.

e-mail: imanuel.aji@ciputra.ac.id
} 
Imanuel Deny Krisna Aji \& Natalia Vike Theresia Sigar / Role of Non Entrepreneur Parents and Entrepreneurial Education in Improving Interest of Entrepreneurship / JEE, Vol. 7, No. 2, September 2018, pp 71-78

Table 1 GDP Per Capita - ASIA Countries 2016-12

\begin{tabular}{lccccc}
\hline \multicolumn{7}{c}{ GDP Per Capita } & List of ASIA Countries 2016-12 & \\
\hline \multicolumn{1}{c}{ Country } & Last & before & The highest & The Lowest & \\
\hline Singapura & 52600.60 & 52245 & 52601 & 3390 & USD \\
Jepang & 47607.70 & 47083 & 47068 & 8608 & USD \\
Hong Kong & 36725.60 & 36191 & 36726 & 3381 & USD \\
Brunei & 31431.00 & 32662 & 66002 & 31431 & USD \\
Korea Sel. & 25458.90 & 24871 & 25459 & 944 & USD \\
Malaysia & 11028.20 & 10740 & 11028 & 1409 & USD \\
Tiongkok & 6894.50 & 6497 & 6894 & 132 & USD \\
Thailand & 5901.40 & 5734 & 5901 & 571 & USD \\
Indonesia & 3974.10 & 3828 & 3974 & 657 & USD \\
\hline
\end{tabular}

Source https://id.tradingeconomics.com

The lack of entrepreneurship has an impact on sustainable economic development problem in the country, and it triggers social problems such as high unemployment (Santoso, 2014). Start up business or entrepreneurship can turn into good potentials offering jobs for the surrounding community.

Table 2 explains the total open unemployment in Indonesia. In 2015 the unemployment rate reached four million. Table 2 explains that the population with a high school education level is more than those from other levels of education. These unemployment problems prove how people find difficult to get jobs. This situation has a negative impact on the sustainability of the country's economy. The numbers of unemployment are inversely proportional to the availability of jobs. This unemployment issue is an important concern when high unemployment is at productive age.

To settle unemployment problems in high school education groups, the education must not be oriented towards job seekers (job seekers) but on job creation (job creator) or entrepreneurship (Suharti \& Hani, 2011). For the unemployed in the senior secondary education group, they are interested in entrepreneurship, Ariyani (2016), reveals three things: self-efficacy, subjective norms, and education. Entrepreneurship education or entrepreneurship education helps provide students with good understanding about entrepreneurship (Ariyani, 2016).

Table 2 Open Income According to Highest Education

\begin{tabular}{llrrrrrr}
\hline & Pendidikan & \multicolumn{2}{c}{2015} & \multicolumn{2}{c}{2016} & \multicolumn{2}{c}{2017} \\
\cline { 3 - 8 } No. & $\begin{array}{c}\text { Tertinggi } \\
\text { yang Ditamatkan }\end{array}$ & \multicolumn{1}{c}{ Feb' } & \multirow{2}{*}{ Agust' } & \multicolumn{1}{c}{ Feb' } & \multicolumn{1}{c}{ Agust' } & \multicolumn{1}{c}{ Feb' } & \multicolumn{1}{c}{ Agust' } \\
\hline 1. & High schools & 1.762 .411 & 2.280 .029 & 1.546 .699 & 1.950 .626 & 1.552 .894 & 1.910 .829 \\
2. & Vocational schools & 1.174 .366 & 1.569 .690 & 1.348 .327 & 1.520 .549 & 1.383 .022 & 1.621 .402 \\
3. & Diploma & 254.312 & 251.541 & 249.362 & 219.736 & 249.755 & 242.937 \\
4. & College & 565.402 & 653.586 & 695.304 & 567.235 & 606.939 & 618.758 \\
\hline & TOTAL & 3.756 .491 & 4.754 .846 & 3.839 .692 & 4.258 .146 & 3.792 .610 & 4.393 .926 \\
\hline
\end{tabular}

Source: Badan Pusat Statistik (2017) 
Imanuel Deny Krisna Aji \& Natalia Vike Theresia Sigar / Role of Non Entrepreneur Parents and Entrepreneurial Education in Improving Interest of Entrepreneurship / JEE, Vol. 7, No. 2, September 2018, pp 71-78

Entrepreneurship education can be understood in many ways. One effective and sustainable way is done through the teaching process. Entrepreneurship education can be invested from basic education or elementary school to university level. Entrepreneurship Education is a potential for students as well as good teachers for the future. Based on previous research, to foster interest in entrepreneurship, students need supports from formal school education.

Apart from formal education institutions, the family environment has a large influence on students to have an interest in entrepreneurship (Utomo et al., 2014). Parents have a big influence for a child to make a choice, for example choosing a school, a department in college, and even a career. This occurs because of the high intensity of meetings, motivation or encouragement, and facilities for their children (A'al, 2016). Based on previous researchers (Utomo et al., 2014), people's views and upbringing influence entrepreneurial mentality.

Children who became the subject of this research came from Generation Z. The birth year period of this generation generally were those born in the birth years of 1995-2010. In Generation Z Indonesia, it was calculated from the year of birth of 1998-2009 and they had the following characteristics: following technological developments, practical, open-minded and active (Subandowo, 2017). This characteristic of Generation $\mathrm{Z}$ is relevant to instilling entrepreneurial interest from an early age.

According to Saiman (2014) there are five principles in entrepreneurship education that can be instilled in students in their learning period, namely: (a) creative and innovative, a mindset formed to find a better way of doing business, namely; able to see opportunities, not easily discouraged, responsible and have initia- tives; (b) acting in a calculated manner in taking risks is a way to observe problems, examine problems, and to prepare preventive actions/ reductions in the risks faced; (c) Optimism, a positive mindset that is formed as a work reference that will succeed well later; (d) sensitive to the market/can read opportunities, an identification activity carried out to see the situation or situation in the target market; (e) independent, an important key in order to avoid dependence on other parties.

Parents, according to Agustin (2011) have two variables, namely a) parents provide motivation or encouragement to build psychological conditions for a child. Such motivation or support can be realized through the provision of facilities (courses, provision of tools/materials, etc.) and communication. b) Parents also train a child's responsibility to complete simple tasks that encourage them to be responsible.

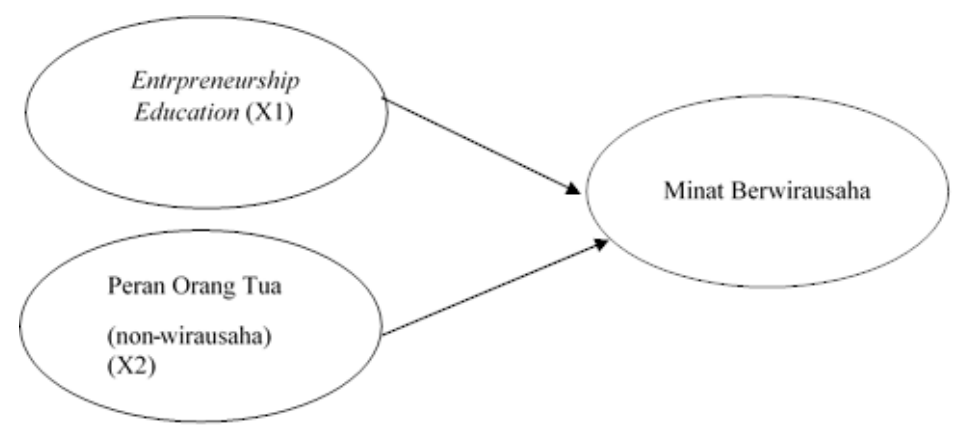

Picture 1 Conceptual Model

With reference to Figure 1, the hypothesis in this study is Entrepreneurship Education and the Role of Parents significantly influences the Interest of Student Entrepreneurship.

\section{Method}

The population of this research was XII graders of CB Surabaya High School. CB Surabaya High School was a school that re- 
Imanuel Deny Krisna Aji \& Natalia Vike Theresia Sigar / Role of Non Entrepreneur Parents and Entrepreneurial Education in Improving Interest of Entrepreneurship / JEE, Vol. 7, No. 2, September 2018, pp 71-78

quired students to learn about entrepreneurship. The vision of entrepreneurship lessons was to achieve Entrepreneurship interest early on. The selection of samples of class XII students at SMA Citra Berkat Surabaya was relevant to the topic of the study regarding the interest in student entrepreneurship. Class XII students got entrepreneurship education from class X-XII during their education at the School. The sampling technique that the researchers used was a purposive sampling technique. The technique was carried out based on the work background criteria of non-entrepreneurial parents.

The research instrument testing was carried out with 2 stages of testing: item analysis through Pearson correlation with a significance level of 0.05 . Meanwhile the Reliability Test is used to determine the consistency of the measuring instrument. The researcher measured the reliable level using Cronbach Alpha with the criteria $\alpha \geq 0.6$ (Ghozali, 2009).

Data obtained in previous studies were be tested using the Classic Assumption Test to ensure that data meets the rules of testing multiple linear regression equations and hypothesis testing. Classical Assumption Test is (a) Normality Test. This test aimed to determine the residual distribution of normal research using diagonal sources on the normal P-P plot of regression standardized graph. (b) Multicollinearity Test aims to test linear relationships in independent variables using the VIF value (variance inflation factor). If the VIF value was less than 10 , multicollinearity did not occur (Ghozali, 2012), (c) The Heteroscedacity test aimed to determine the state of the absence of variants of the residuals in the regression model. (d) Linearity test was used to determine the linearity of the data by using a significance value of less than 0.05 .
The discussion between the variable Entrepreneurship Education and the Role of Parents with Interest in Entrepreneurship was based on the results of testing the correlation coefficient and coefficient of determination. The correlation coefficient showed the strength between variables based on numbers between $0-1$. The determination coefficient aimed to measure the ability of the model in explaining the variation of the dependent variable. The coefficient of determination had a value of $0-1$. The more the value approaches 1 means that the independent variable was able to predict variations in the related variables. Multiple linear regression testing explains the relationship or influence between the dependent variable and several independent variables. The testing of multiple linear regression models was seen from Test $F$. This was to test whether the model from regression was significant or not. Then testing the hypothesis by using the $t$ test which partially showed how far the independent variables explained the variation of the dependent variable.

\section{Results}

Testing the data through the classic assumption test is carried out before multiple linear regression testing.

Table 3 shows that the significance value of the Kolmogorov-Smirnov test is 0.076 and is greater than 0.05 so it can be concluded that the residuals are normally distributed (the population of data is normally distributed). This shows the feasibility of linear regression analysis techniques in this study. The heteroscedicity test was conducted to test whether in the regression model vanilla inequality occurred from residual or other observations. This research heteroscedicity test uses the Gleiser test. Significance value $>0.05$ so that there are no symp- 
Imanuel Deny Krisna Aji \& Natalia Vike Theresia Sigar / Role of Non Entrepreneur Parents and Entrepreneurial Education in Improving Interest of Entrepreneurship / JEE, Vol. 7, No. 2, September 2018, pp 71-78

Table 3 Summary of Classical Assumption Test Results

\begin{tabular}{|c|c|c|c|}
\hline \multicolumn{4}{|l|}{ Normality Unstandardized Residual } \\
\hline Test Statistic & \multicolumn{2}{|c|}{1.278} & \\
\hline Asmp. Sig. (2-tailed) & \multicolumn{2}{|c|}{0.076} & Normal distribution \\
\hline Heteroscedasticity & \multicolumn{2}{|c|}{ Sig. } & \\
\hline Entrepreneurship Education $\left(\mathrm{X}_{1}\right)$ & \multicolumn{2}{|c|}{0.464} & No Heteroskedesitas \\
\hline Role of parents (Non-entrepreneurs) $\left(\mathrm{X}_{2}\right)$ & \multicolumn{2}{|c|}{0.792} & No Heteroskedesitas \\
\hline Multicollinearity & Tolerance & VIF & \\
\hline Entrepreneurship Education $\left(\mathrm{X}_{1}\right)$ & 0.756 & 1.323 & No Multikolineritas \\
\hline Peran Orang Tua (Non-entrepreneurs) $\left(\mathrm{X}_{2}\right)$ & 0.756 & 1.323 & No Multikolineritas \\
\hline Linearity & \multicolumn{2}{|c|}{ Sig. Linearity } & \\
\hline Entrepreneurship Education $\left(\mathrm{X}_{1}\right)$ & \multirow{2}{*}{\multicolumn{2}{|c|}{$\begin{array}{l}0.002 \\
0.000\end{array}$}} & Linear correlation \\
\hline Role of parents (Non-entrepreneurs) $\left(X_{2}\right)$ & & & Linear correlation \\
\hline
\end{tabular}

toms of heteroscopy. This shows the feasibility of multiple linear regression analysis techniques in this study.

It is also known that the VIF value of the Entrepreneurship Education variable and the Role of Parents (Non-Entrepreneurs is 1,323 and smaller than 10 , so there is no multicollinearity in this study and it can be concluded that among the independent variables is not interconnected. This shows the feasibility of regression analysis techniques multiple linear in the study Linearity test aims to determine whether the variable has a linear relationship significantly or not. The provision of testing in this study is the significance value of linearity $<0.05$.

The linear significance value of Entrepreneurship Education variables is 0.002 and $<0.05$. It was concluded that the Entrepreneurship
Education variable had a linear relationship with an interest in entrepreneurship. The linear significance value of the Parent (Non-Entrepreneur) Role variable is 0,000 and $<$ from 0.05 . It is concluded that the Parent Role (Non-Entrepreneur) variable has a linear relationship with the interest in entrepreneurship.

The next process is to observe the results of multiple linear regression testing. This can be seen in Table 4 .

Table 4 explains the value of $\mathrm{R}$ or the value of the correlation coefficient is 0.719 or $71.9 \%$. This means there is a correlation between the independent variables (Entrepreneurship Education and the Role of Parents (Non-Entrepreneurs) to the dependent variable (Entrepreneurial Interest). The correlation is positive and strong (close to 1). Adjusted R Square Value (Adj $\mathrm{R}^{2}$ ) or coefficient value determination of

Table 4 Results of Multiple Linear Regression Analysis

\begin{tabular}{lcccccc}
\hline \multicolumn{1}{c}{ Model } & B & $\mathbf{R}$ & $\begin{array}{r}\text { Adjusted } \\
\text { R square }\end{array}$ & F & T & Sig. \\
\hline (Constanta) & -1.003 & 0.719 & 0.479 & 13.400 & & 0.000 \\
Entrepreneurship Education $\left(\mathrm{X}_{1}\right)$ & 0.541 & & & & -1.068 & 0.054 \\
Parents (Non-Entrepreneurs) $\left(\mathrm{X}_{2}\right)$ & 0.687 & & & & 2.020 & 0.004 \\
\hline
\end{tabular}


Imanuel Deny Krisna Aji \& Natalia Vike Theresia Sigar / Role of Non Entrepreneur Parents and Entrepreneurial Education in Improving Interest of Entrepreneurship / JEE, Vol. 7, No. 2, September 2018, pp 71-78

0.479 shows the percentage of the ability of independent variables (Entrepreneurship Education and the Role of Parents (Non-Entrepreneurs)) in explaining the dependent variable (interest in entrepreneurship) by $47.9 \%$, while the remaining $52.1 \%$ is influenced by other variables not discussed in the study this.

The results of multiple linear regression equations show that the constant is -1.003 , the regression coefficient of Entrepreneurship Education coefficient is 0.541 and the coefficient of the Role of Parents (Non-Entrepreneurs) is 0.687. The multiple linear regression equation has a negative constant value of -1.003 . This finding reflects if Entrepreneurship Education and the Role of Parents (Non-Entrepreneurs) are worth zero, Interest in Entrepreneurship will be negative. The model implies that every increase in one unit score of application in the Entrepreneurship Education variable of 0.541 will be followed by an increase in Interest in Student Entrepreneurship by -1.003 with the assumption that the variable Role of Parents (Non-Entrepreneurs) in the condition remains. Every increase in one unit score of application on the Parent (Non-Entrepreneur) Role variable of 0.639 will be followed by an increase in Interest in Student Entrepreneurship by -1.003 assuming that the Entrepreneurship Education variable in the condition remains.

The analysis model testing is done by using the $\mathrm{F}$ Test. It aims to examine whether the analysis model can be accepted by statistical tests. Based on Table 1.4, it is known that the significance value of the F Test is 0,000 . This means the value is less than 0.05 . As a result, it is concluded that the Entrepreneurship Education variable and the Role of Parents (NonEntrepreneurs) simultaneously influences the interest in entrepreneurship.
Hypothesis testing is done using $\mathrm{t}$ test. Partially, the independent variable influences the dependent variable. Table 4 shows that the significance value of the $t$ test for variable $\mathrm{X} 1$ is 0.054 . This value is greater than 0.05 . It was concluded that the Entrepreneurship Education variable did not have a partial influence on the interest in entrepreneurship (Y). The significance value of the $t$ test for variable $\mathrm{X} 2$ is 0.004: the value is smaller than 0.05. It was concluded that the Parent Role (Non-Entrepreneur) variable has a partial influence on the interest in entrepreneurship $(\mathrm{Y})$.

\section{Discussion}

The phenomenon that occurs from the results of this study is quite interesting. The results of hypothesis testing indicate that nonentrepreneurial parents influence the interest in entrepreneurship in class XII students. This finding is very contradictory where children often follow in the footsteps of their parents in general.

The role of parents' variable (Non-Entrepreneurs) significantly influences students' interest in entrepreneurship. The results of this study are in line with the results of research conducted by Emeralda and Kristiana (2017) which states that the Role of Parents (NonEntrepreneurs) significantly influences the intention of student entrepreneurship.

The statement with the smallest standard deviation is 0.693 . Parental supports that provide facilities for students. This finding shows that the respondents have a homogeneous (consistent) statement. This means that all students agree if each of their parents supports them by providing facilities to build their business. If the Parents' Roles influence the Interest of Entre- 
Imanuel Deny Krisna Aji \& Natalia Vike Theresia Sigar / Role of Non Entrepreneur Parents and Entrepreneurial Education in Improving Interest of Entrepreneurship / JEE, Vol. 7, No. 2, September 2018, pp 71-78

preneurship, non-entrepreneurial parents can enter their children into schools that are branding to run Entrepreneurship as a distinctive feature of the school.

It is inversely proportional to the results of hypothesis testing in the Entrepreneurship Education variable. Based on the results of testing the hypothesis by using the results of the significance of the $t$ test, it shows that the Entrepreneurship Education variable (X1) does not have a significant effect partially on the interest in entrepreneurship in class XII students. The results of this study are in line with the research of Mutohar (2017), namely entrepreneurship education does not significantly influence students' entrepreneurial intentions.

The results received clarification from several respondents who we observed and interviewed further. Some of them said that in the school there was a lack of special Entrepreneurship teachers that students could trust as an entrepreneur. This lack of recognition of capabilities in the Entrepreneurship field is one reason for the lack of influence of Entrepreneurship Education to increase interest in entrepreneurship for students of class XII. This results in a lack of in-depth theory or practice from the instructor, and tedious delivery of material so that the implementation of classroom learning is less attractive and does not foster interest in student entrepreneurship.

The negative constant values in multiple linear regression equations in the analysis model are interesting findings. The value of dance in practice can indicate the condition or initial condition of the sample as a representative of the population about the interest in student entrepreneurship. The description of these conditions allows further discussion on how entrepreneurship interests are experienced by class
XII students. The statement of negative values can be interpreted that at the beginning or the initial conditions indeed the students are not interested in entrepreneurship so that the magnitude of the influence of the independent variables cannot be clearly seen or felt by all students.

Based on respondents' data, $43 \%$ of respondents were male and $57 \%$ of respondents were female. The majority of respondents are 17 years old (79\%). The final semester students in class XII are students who are respondents to this study. The researchers conclude that students who possessed an interest in entrepreneurship are mostly women aged 17 years. They are final semester students in class XII.

Students who are the sample of this study come from Generation Z. The birth year period of this generation generally comes from the years of birth from 1995 to 2010 with characteristics from Generation Z: updated with technological developments, are practical, open minded and active (Subandowo, 2017). It is possible to make decisions more quickly in entrepreneurship or not, thus influencing the decision to be interested in entrepreneurship or not.

\section{References}

A'al, R. 2016. Perhatian Orang Tua dan Motivasi Belajar Siswa. Jurnal Madaniyah, 2(11), 249-268.

Agustin, D.M. 2011. Permasalahan Belajar dan Inovasi Pembelajaran. Bandung: Refika Aditama.

Ariyani, L. 2016. Faktor-Faktor yang Mempengaruhi Intensi Berwirausaha pada Kalangan Mahasiswa. Publikasi Ilmiah. Surakarta: Fakultas Ekonomi dan Bisnis Universitas 
Imanuel Deny Krisna Aji \& Natalia Vike Theresia Sigar / Role of Non Entrepreneur Parents and Entrepreneurial Education in Improving Interest of Entrepreneurship / JEE, Vol. 7, No. 2, September 2018, pp 71-78

Muhamadiyah Surakarta. Retrieved from http://eprints.ums.ac.id/46263/17/NASKAH\%20PUBLIKASI.pdf.

BPS. 2017. Pengangguran Terbuka Menurut Pendidikan Tertinggi. Diambil Kembali dari Badan Pusat Statistik: https:/www.bps.go.id/ statictable/2009/04/16/972/pengangguranterbuka-menurut-pendidikan-tertinggiyang-ditamatkan-1986-2017.html

Economics, T. 2018. PDB per Kapita - Daftar Negara - Asia. Diambil Kembali dari Trading Economics: https://id.tradingeconomics.com?country-list/gdp-per-capita?continent $=$ asia

Emeralda, G.W. \& Kristiana, I.F. 2017. Hubungan antara Dukungan Sosial Orang Tua dengan Motivasi Belajar pada Siswa Sekolah Menengah Pertama. Jurnal Empati, 7(3), 154-159.

Ghozali, I. 2009. Aplikasi Analisis Multivariate dengan Program SPSS. Semarang: Undip.

Ghozali, I. 2012. Aplikasi Analisis Multivariate dengan Program IBM SPSS 20. Semarang: Undip.

Mutohar, A. 2017. Pengaruh Kebutuhan Akan Prestasi, Efikasi Diri, Kesiapan Instrumen, dan Pendidikan Kewirausahaan terhadap
Intensi Berwirausaha Mahasiswa. Skripsi Thesis. Surakarta: IAIN Surakarta. Retrieved from http://eprints.iain-surakarta. ac.id/321/.

Saiman, L. 2014. Dasar-Dasar Kewirausahaan. Jakarta: Salemba Empat.

Santoso, I. 2014. Masalah dan Tantangan Pengembangan Kewirausahaan pada Kalangan Mahasiswa di Indonesia. Jurnal Inovasi dan Kewirausahaan, 3(3), 203-207.

Subandowo, M. 2017. Peradaban dan Produktivitas dalam Perspektif Bonus Demografi serta Generasi Y dan Z. Jurnal Pendidikan Sains Sosial dan Kemanusiaan, 10(2), 191208.

Suharti, L. \& Sirine, H. 2011. Faktor-Faktor yang Berpengaruh terhadap Niat Kewirausahaan (Entrepreneurial Intention): Studi terhadap Mahasiswa Universitas Kristen Satya Wacana, Salatiga. Jurnal Manajemen dan Kewirausahaan, 13(2), 124-134.

Asriati, N., Utomo, B.B., \& Mashudi. 2014. Pengaruh Pendidikan Kewirausahaan dalam Keluarga dan di Sekolah terhadap Minat Berwirausaha dengan Mediasi Self-Efficacy Siswa Kelas XI. Pontianak. E-Jurnal Manajemen Untan, 3(4), 1-15. 